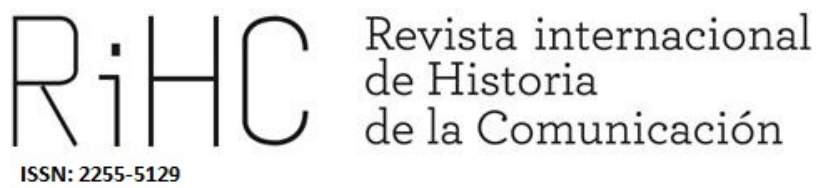

\title{
LA CONSTRUCCIÓN DEL DISCURSO PERIODÍSTICO DE LA REVISTA CARAS Y CARETAS FRENTE A LA REPRESIÓN DE LA SEMANA TRÁGICA DE 1919
}

The magazine's journalistic construction Caras y Caretas in the repression of the "Semana Trágica" ("Tragic week") in 1919

DOI: http://dx.doi.org/10.12795/RiHC.2018.i10.12

Recibido: 26/03/2018

Aceptado: $25 / 05 / 2018$

Publicado: $25 / 06 / 2018$

María Fabiola Di Mare L. (D) https://orcid.org/0000-0003-1995-8203

CONICET-CEHICOPEME- Facultad de Periodismo y Comunicación

UNLP, fdimare@gmail.com

Resumen: La revista Caras y Caretas, como publicación semanal de actualidad, estructuró un discurso acerca de los conflictos obreros durante la época radical (19161930), con las cuales ofreció su postura frente a las tensiones sociales y políticas de la época. En ese sentido, se indaga la construcción periodística de la publicación ante el reclamo de los sectores obreros en los hechos de la denominada Semana Trágica de 
1919. La investigación toma para el análisis los aportes teórico-metodológicos de Roger Chartier, Miguel Rodrigo Alsina, Roberto Marafioti, Héctor Borrat, entre otros. Entre las conclusiones obtenidas, se demostró la posición del semanario como actor político de cara a los conflictos obreros y en el marco de las relaciones de dominio instituidas. Construyó un discurso que presentó realidades dicotómicas o pares antagónicos entre un "ellos" y un "nosotros", los cuales además se diferenciaban por principios de superioridad e inferioridad y de la necesidad de asimilar o proscribir a quienes no encajaban en el orden establecido. A través de diversas estrategias discursivas, la revista legitimó prácticas represivas por parte de la policía, el Ejército y del sector parapolicial Liga Patriótica Argentina.

Palabras clave: Semana Trágica argentina, represión, huelga, discurso.

\begin{abstract}
The magazine Caras y Caretas, as a current weekly, lead a speech about the workers conflicts during the radical period (1916-1930), through which it offered it position against the social and political tensions of the epoch. In that sense, the publication's journalistic construction is inquired due to the workers sectors claims in what is known as "Semana Trágica" ("Tragic week") in 1919. The research takes into account the theorical- methodological approaches for the analysis, as well as Roger Chartier, Miguel Rodrigo Alsina, Roberto Marafioti, Hector Borrat, among others. It was determined that journal position as a political actor face to the worker issues and with the power relations installed. It structured a speech that showed the dichotomous facts or antagonic pairs between "them" and "us", who were also distinguised by superiority and inferiority principles and the need of setting aside to the ones that did not fit in the status quo. Through the different discursive strategies, the magazine legitimized repressive practices of the police, the Army and the parapolicial sector Liga Patriótica Argentina (Argentine Patriotic League).
\end{abstract}

Keywords: Argentinian tragic week, repression, strike, speech.

\title{
Introducción
}

Caras y Caretas fue una revista de enfoque masivo y popular, cuyas marcas distintivas se definieron desde el primer número publicado el 08 de octubre de 1898 con el subtítulo en portada "Seminario festivo, literario, artístico y de actualidades". La publicación tiene una importancia singular en la historia del periodismo argentino por su carácter de pionera en cuanto a su producción y circulación como revista comercial, cultural y literaria, en la cual se reflejaron los sucesos de la historia política y social del momento, así como los modos de vida, las costumbres y el clima intelectual de la época.

La revista Caras y Caretas se constituyó en una publicación con miras a convertirse en empresa mercantil, sin descuidar por ello la calidad de sus contenidos y la cuidadosa presentación visual de cada uno de sus números. El semanario mantuvo un formato 
versátil y cómodo para su lectura, bien sea en el tranvía, de camino al trabajo o en cualquier lugar.

El campo de las revistas y publicaciones periódicas en los albores del siglo XX era muy amplio. En el periodo decimonónico hubo una prolífica cantidad de periódicos y revistas en el Río de La Plata. Se puede destacar la revista Don Quijote (1884-1891), para la cual colaboraba José Sixto Álvarez, quien fue director de Caras y Caretas.

A principios del siglo XX se contabilizaron 12 diarios y 353 publicaciones periódicas solo en Buenos Aires, mientras que en todo el país el número de periódicos ascendía a 831 (Saítta, 2013). Comenzando la centuria circulaban revistas como La Argentina (1901), PBT (1904), Fray Mocho (1913) y Atlántida (1918).

Eduardo Romano (2004) señala que entre los atributos más significativos de la revista está el hecho de que procesó la actualidad de acuerdo a las expectativas del público, constituido primordialmente por lectores heterogéneos, conformados por las nuevas masas de trabajadores y citadinos alfabetizados y ávidos de consumir productos culturales. Esto indica que desde el principio el semanario estableció un contrato de lectura definido con sus lectores, para quienes la lectura era un pasatiempo o una forma de ocio y por ello preferían los textos rápidos, amenos, pero al mismo tiempo críticos y citadinos, acorde a las condiciones del momento.

La revista comenzó a circular en un contexto marcado por una atmósfera cultural democratizadora producto del aporte de la inmigración, la explosión urbana y la conformación de un sector social intermedio, que Gutiérrez y Romero (2007) prefieren denominar como sectores populares urbanos. Se trata de un público indefinido, cambiante, más preciso por sus gustos, que se va construyendo a partir de identidades, percepciones y experiencias, en términos de Thompson (1989), más que por su verdadera posición de clase en el entramado de las relaciones de producción. Es lo que Bourdieu (2012) denominó habitus, es decir, las disposiciones adquiridas o las actividades que delimitan fronteras de clase, lo cual se percibe en los gustos musicales, las modas, las formas de alimentarse, las actividades recreativas y de ocio y todo lo que coadyuva a construir distinciones en las posiciones sociales.

El discurso periodístico construido por Caras y Caretas se ajustaba a las expectativas o al universo simbólico que configuró la revista sobre sus lectores. Siguiendo los criterios de Chartier (1992), se entiende que un texto no solo expresa la visión de quien lo produce, sino que también es producido por la imaginación e interpretación del lector. En ese sentido, de acuerdo a las capacidades, expectativas y prácticas de la comunidad a la que pertenece un texto, éste establece un sentido particular. Esto hace suponer que toda publicación periódica no solo es el resultado de lo que construyen sus editores, sino que su estructura está gobernada por las formas de lectura que los editores aprecian de los lectores que aspiran conquistar. De tal manera que el 
semanario emplea formas livianas, como caricaturas, ilustraciones y fotografías, para presentar su versión sobre el hecho.

El semanario fue parte del proceso de ensanchamiento de la esfera pública. Rogers (2018), quien emprendió una investigación sobre la revista durante el periodo 18981904, indica que "su lógica integradora muestra el trabajo cultural permanente de reconstitución hegemónica, en su asombrosa capacidad de articular interpelaciones de naturaleza diferente y minar el carácter revulsivo de toda confrontación" (18). Sin embargo, esta posición de Caras y Caretas como integradora y ajena a la confrontación queda en entredicho al examinar en profundidad su postura frente a los conflictos obreros, las huelgas y levantamientos populares que tuvieron lugar durante el periodo radical argentino (1916-1930), como la que se analiza en esta investigación, la Semana Trágica de enero de 1919, denominación incorporada por la propia revista y con el cual pasó a la historia esta revuelta social.

Caras y Caretas fue fundada en Montevideo, en 1890, por Eustaquio Pellicer. Este era un inmigrante oriundo de Burgos, que llegó a Uruguay a los 27 años. Tenía una amplia trayectoria en el campo periodístico y justo después de su arribo a ese país fundó la revista Pellicerina. Esta primera Caras y Caretas tuvo dos épocas: desde 1890 hasta el 28 de febrero de 1892 y luego de marzo de 1894 a febrero de 1897. Durante la primera etapa, como lo refiere Díaz (2018), la revista manejó una ideología afín a las doctrinas liberales y al pensamiento francés. Fomentaba los valores e ideales de civismo y la modernización de la nación. Este propósito era parte del pensamiento de la intelectualidad de la época, la cual, a través de las revistas ilustradas buscaba forjar ciudadanos para la paz, el orden y el progreso (Di Mare, 2010).

En 1892 Pellicer se trasladó a Buenos Aires y en la capital porteña decidió refundar Caras y Caretas, para lo cual le pidió a Bartolomé Mitre y Vedia, hijo del fundador del diario La Nación, que fuese su director. Rogers (2008) hace un relato de esto:

La guerra de Cuba había generado susceptibilidades que hacían inconveniente poner a un español como responsable de la publicación, así que convocó a Bartolomé Mitre y Vedia, un criollo experimentado. El ex director del diario La Nación e hijo mayor de su fundador aceptó el ofrecimiento y su nombre apareció en el anuncio previo a la inminente salida de la revista (Rogers, 2008: 30).

No obstante, Mitre y Vedia abandonó la dirección cuando el primer número estaba en prensa, excusándose mediante una comunicación pública en la primera edición. Luego del incidente, José Sixto Álvarez, conocido por su seudónimo Fray Mocho, fue convocado para dirigirla. Este último, periodista del diario La Nación, quince años antes había fundado la revista Fray Gerundio y también trabajó junto al dibujante Eduardo Sojo en la revista humorística de marcada orientación política, Don Quijote. 
Puede decirse que desde 1898 hasta 1904 se cumple una primera etapa de Caras y Caretas. A partir de 1904 se suceden cambios en su dirección con el alejamiento de Eustaquio Pellicer y la muerte de José Sixto Álvarez. Esto provoca una impronta más empresarial y comercial, que se evidenció con el aumento de los anuncios publicitarios y el incremento notable de contenido ${ }^{1}$.

La etapa de Caras y Caretas que se analiza en esta investigación, corresponde a una época poco estudiada de la publicación, en la cual se suceden hechos trascendentales para la Argentina, dado que se aprobó en 1912 una nueva Ley Electoral, conocida como Ley Sáenz Peña, promulgada por el presidente homónimo, la cual estableció el voto masculino obligatorio y secreto a través del padrón militar. Esto permitió el ascenso del partido Unión Cívica Radical (UCR) al poder durante catorce años, con la primera presidencia de Hipólito Yrigoyen (1916-1922), el gobierno de Marcelo Torcuato de Alvear (1922-1928) y la segunda presidencia de Yrigoyen (1928-1930).

El periodo democrático se extendió hasta 1930 con el derrocamiento de Yrigoyen mediante un golpe de Estado y el inicio de una etapa en la que nuevamente se instituye el fraude electoral, un periodo conocido en la historia como "la década infame".

De acuerdo a lo que exponen autores que han estudiado la época radical, como David Rock (2010) o Joel Horowitz (2015), con la primera presidencia de Yrigoyen (19161922) toman visibilidad los conflictos obreros, principalmente por reclamos reivindicativos. Las huelgas que ocurrieron en la primera presidencia de Yrigoyen fueron una consecuencia de los efectos de la inflación sobre los salarios durante la guerra y la posguerra inmediata.

Durante los años 1916-1917 se sucedieron las huelgas marítimas como parte de los reclamos de los trabajadores del puerto de La Boca, agrupados en la Federación Obrera Marítima (FOM), quienes interrumpieron el embarque de los productos de las cosechas en los barcos para presionar a las empresas navieras extranjeras para obtener mejores condiciones salariales. En la huelga de enero de 1917, el gobierno apoyó las reivindicaciones de los trabajadores y medió ante las empresas, dada la importancia estratégica de mantener el control y el favoritismo de los sindicatos marítimos. El objetivo de Yrigoyen fue ganar rédito político con la popularidad y el favoritismo del barrio de La Boca, un sector de trabajadores muy importante en la ciudad de Buenos Aires.

Rock (2010) expone que para 1917-1918 se suscitaron las huelgas ferroviarias organizadas por los principales sindicatos, La Fraternidad y la Federación Obrera

\footnotetext{
${ }^{1}$ Una edición de Caras y Caretas de 1898 contaba con no más de 30 páginas y para 1905 ya alcanzaba 75 páginas. Cada ejemplar del semanario tenía para 1916 un número de páginas que oscilaba entre 80 y 100. Este aumento en el tiempo indica que fue incrementando significativamente su ámbito de recepción.
} 
Ferroviaria (FOF) para exigir aumentos salariales, jornada laboral de ocho horas, plan de jubilación y reincorporación de despedidos durante la huelga, exigencias que eran reclamadas desde 1912. En estas huelgas que intervino el gobierno a favor de los sindicatos, debido a la gran cantidad de trabajadores involucrados. Debe agregarse que estos conflictos tuvieron la originalidad de que un presidente de la República recibiera a una comitiva sindical en la Casa de Gobierno.

De esta manera, el primer periodo presidencial de Yrigoyen estuvo marcado por los conflictos y las huelgas obreras. Una de las más grandes revueltas sociales de la época fue la Semana Trágica argentina de enero de 1919, que incluyó una huelga general de trabajadores, originada por las reivindicaciones de los trabajadores de la empresa privada Talleres Metalúrgicos Vasena.

\section{La Semana Trágica: el obrerismo hasta cierto límite}

El estallido de la Primera Guerra Mundial en 1914 hizo que el país experimentara una depresión económica que deprimió los salarios y deterioró las condiciones de vida de los trabajadores. Gerchunoff (2016) explica que el shock negativo se debió principalmente al recorte de los flujos comerciales internacionales, que a su vez repercutió en el mercado interno debido a los efectos que sobre la oferta de bienes importados tenía el valor de los seguros y los fletes.

En ese sentido, durante el conflicto bélico, así como en la posguerra inmediata, se profundizó una regresión en los salarios, un incremento de la inflación y aumento del desempleo, que en 1917 rondaba el 20\%, según datos de Gerchunoff (2016). Este contexto laboral tuvo como agregado las precarias condiciones laborales existentes, en especial en empresas de capital extranjero.

Las consecuencias negativas de la guerra se vivieron hasta 1918, momento en el que diversos sectores económicos comenzaron a crecer y consecuentemente se incrementó de nuevo la demanda de trabajo. De ese modo, se inició un clima propicio para que los gremios laborales exigieran reivindicaciones y además fortaleciesen su posición de negociación. Es por esta razón que al año siguiente, en 1919, se contabilizaron 259 huelgas, en las que tuvieron participación 309.000 trabajadores, de acuerdo a estadísticas de David Rock (2010).

En 1919 se desencadenó una de las huelgas más relevantes hasta el momento en la historia de Argentina, conocida como la Semana Trágica, denominación incorporada por la propia revista Caras y Caretas. El que un medio masivo como éste estableciera 
un título o una denominación para estos hechos y que esa cobertura periodística perdure inalterable 100 años después, indica que hubo unas marcas simbólicas del enunciador que trascendieron a sus lectores. Hubo un juego de correspondencias entre el lector y la revista, o entre el locutor y el receptor en la enunciación del discurso, que le otorgan una importancia singular a la cobertura periodística realizada por el semanario.

La huelga de enero de 1919 tiene su origen en los Talleres Metalúrgicos Vasena, a causa de reclamos reivindicativos por parte de sus trabajadores, quienes exigían a la empresa jornada diaria de 8 horas, aumento de $20 \%$ en los jornales superiores a 4.99 pesos, aumento de $30 \%$ en los jornales de 3 a 4.99 pesos, $100 \%$ de prima en el salario dominical. Además de esto, el diario La Nación reseñó que los trabajadores solicitaban mejoras en las condiciones laborales, la eliminación del trabajo a destajo y por último, eliminar las represalias contra los trabajadores en huelga.

La directiva de Vasena hizo caso omiso a las exigencias de sus trabajadores, quienes desde diciembre de 1918 sostenían una huelga. La empresa desoía los reclamos y siguió operando con obreros no adheridos y mediante el contrato de rompehuelgas².

El conflicto laboral tomó proporciones significativas cuando el 7 de enero de 1919, los trabajadores huelguistas encaran con improperios, palos y piedras, a un grupo de rompehuelgas, en el momento en que éstos últimos se dirigían hacia los depósitos de la empresa en busca de materia prima para la planta industrializadora. Ante la actitud de los huelguistas, la policía respondió cargando contra hombres, mujeres y niños. Este hecho violento arrojó 4 muertos y una decena de heridos, algunos de los cuales fallecieron posteriormente (Godio, 1985).

El conflicto cobró amplias dimensiones políticas y sociales cuando al día siguiente se produjo un enfrentamiento entre la policía y los obreros que trasladaban el cortejo fúnebre, con los muertos del día anterior, hacia el cementerio de La Chacarita.

El enfrentamiento violento entre policías y huelguistas propició un motín en las calles y la intervención armada de la policía, que reprimió fuertemente a los manifestantes. La semana trágica arrojó centenares de muertos, además del caos en las calles de la capital y en varias provincias (Bilsky, 1984). Estos hechos fatales desencadenaron la convocatoria a un paro general por parte de los principales gremios laborales de la época, agrupados en la FORA del IX Congreso.

Para este momento existía una división en el movimiento obrero, el cual se agrupaba en dos centrales obreras: la FORA del IX ${ }^{\circ}$ y la FORA del $V^{\circ}$ Congreso. En el primero se agrupan los socialistas y la vertiente sindicalista o "neutral", es decir, aquella que

\footnotetext{
${ }^{2}$ En España este término se conoce como esquirol. En Uruguay, Argentina y Paraguay se les llama carnero o crumiro.
} 
postula la no adhesión de posturas ideológicas o políticas, es decir, es proclive a las solicitudes netamente reivindicativas. En la FORA del $\mathrm{V}^{\circ}$ se ubican los partidarios del comunismo anárquico, también Ilamados anarcosindicalistas. Estos últimos concebían cada conflicto como una oportunidad para luchar contra el capital y hacer una revolución social profunda.

La FORA del $V^{\circ}$ toma como inspiración a la Revolución de Octubre de 1917 y a las revoluciones del proletariado que se suscitaban en ese momento en Europa. A su vez, toman el concepto de huelga general revolucionaria formulada por la Confédération Générale du Travail (CGT) francesa, en octubre de 1906. Esta última apostó por el apoliticismo y consideraba el sindicato como el instrumento necesario que había de transformar la sociedad en clave revolucionaria, a través de una huelga general revolucionaria.

La huelga general incluyó a los obreros marítimos, que sostenían una protesta desde hacía un mes, así como los obreros ferroviarios. De allí la trascendencia política del conflicto.

Esta Semana Trágica, hecho llamado de esa forma por la propia Caras y Caretas, se convirtió en la huelga más importante que hubiera tenido la Argentina hasta ese momento. El conflicto trajo repercusiones políticas para el gobierno yrigoyenista, principalmente debido a su posición ambigua en la situación. En una primera fase permitió la represión, pero frente a las presiones por la activación de la huelga general tuvo que ejercer de mediador entre la empresa y el sindicato.

El mayor temor de las clases dominantes fue la posibilidad latente de que estos sucesos se convirtiesen en el inicio de una revolución obrera que pusiese en jaque al Estado y al modelo. Los ecos de la Revolución de Octubre de 1917 y de los estallidos obreros de Europa, como la también denominada Semana trágica española de 1909 o la huelga general revolucionaria de 1917 en España. Esto retumbaba en los oídos de una élite que deseaba una respuesta severa y decidida de parte del gobierno contra las protestas laborales.

Para las élites oligárquicas argentinas, la cuestión obrera pareció desbordarse a partir de la Semana Trágica. Al mismo tiempo, los sucesos mostraron la actitud diferencial de la gestión yrigoyenista en materia sindical, la cual tenía relación con criterios como la centralidad para la economía de la actividad en la que se registraba la conflictividad o se vinculaba con intereses partidarios concretos. Una fotografía de Caras y Caretas de fecha 13 de octubre 1917, en la que se ve cómo Alejandro Ruzo, jefe de la División Legislación del Departamento Nacional del Trabajo (DNT), dialoga con dirigentes sindicales y trabajadores, comprueba la actitud distintiva del gobierno frente a las huelgas ferroviarias, un sector clave para la economía nacional. 
En conflictos como el ferroviario, así como en las huelgas marítimas, el gobierno intervino como mediador y se mostró favorable a los reclamos sindicales. En cuanto a la protesta de Vasena, la respuesta fue la represión. Además, en estos hechos intervino otro factor, el Ejército, específicamente las tropas de Campo de Mayo, al mando del comandante Luis Dellepiane.

Del mismo modo, las fuerzas conservadoras, que venían asumiendo una postura antiobrera a través de la patronal Asociación del Trabajo, constituyen a partir de los hechos de la Semana Trágica la denominada Liga Patriótica Argentina, con lo cual inician una persecución, con fuerzas de choque paraestatales, contra líderes obreros y factores considerados "maximalistas", es decir, ácratas y comunistas que aprovecharon el escenario para iniciar una revolución. La Liga también participó activa y directamente en la represión y masacre contra los obreros de las estancias de Santa Cruz.

\section{Caras y Caretas y la Semana Trágica}

De acuerdo con Ducrot (2011), el proceso comunicacional está compuesto por un emisor, quien es el locutor o enunciador. Éste organiza su discurso como un juego de relaciones entre él y su receptor, el cual está impregnado de marcas definidas o unas huellas.

Este planteo coincide con Marafioti (1998), en el sentido de que, el medio de comunicación enuncia un discurso dentro del cual crea un mundo discursivo, semejante, o no, al que consideramos real. Esto quiere decir que hay una voluntad comunicativa explícita del hablante que enuncia y un juego de correspondencias con respecto al alocutor o receptor.

Este juego se inscribe en lo que Marafioti (1998) menciona como una comunidad cultural e ideológica que se rige por ciertas normas que el locutor asume como válidas para sí y para su receptor. En consecuencia, se comprueba que mediante estas huellas es posible leer no sólo la subjetividad individual sino principalmente una subjetividad socialmente compartida.

En este sentido, las huellas se conforman por frases, palabras, morfemas o entonaciones particulares que permiten leer en un enunciado cómo el locutor selecciona, destaca u omite entidades de la situación comunicativa. Del mismo modo, también se encuentran "marcas para ser leídas las valoraciones que el locutor hace del mundo que representa denominadas subjetivemas" (Marafioti, 1998: 133). 
A propósito de estas huellas o marcas, que dejan una impronta ideológica de parte del locutor en la enunciación, también es preciso mencionar la utilización del recurso discursivo que establece realidades dicotómicas o "pares antagónicos" (Díaz, 2007: 109), los cuales se utilizan para crear construcciones binarias, que puede ser "ellos" y "nosotros", "nación" e "imperialismo", "civilización" y "barbarie" (Díaz, 2007: 193).

En esta investigación también se toma la perspectiva teórica de Borrat (1989), quien postula que los medios de comunicación son actores en el sistema político, "entendiendo por actor político a todo actor colectivo o individual capaz de afectar al proceso de toma de decisiones en el sistema político" (Borrat, 1989: 10). Por tanto, este tipo de información de tanta trascendencia y publicada por un medio masivo y popular como Caras y Caretas, tiene el propósito político de influir en las decisiones y en el manejo de la crisis por parte de los principales actores involucrados: por un lado, el gobierno y las fuerzas de seguridad estatales, los trabajadores huelguistas y los grupos dominantes patronales aglutinados en la Liga Patriótica Argentina.

Borrat (1989) también establece que los conflictos políticos se originan en las relaciones de dominio que existen dentro de la estructura social, es decir, los conflictos son recurrentes en las sociedades en las que existen asociaciones de dominio de supra y subordinación entre grupos e individuos. Estas mismas estructuras de dominación tienen presencia en los medios mediante las inclusiones, exclusiones y jerarquizaciones que hacen en sus temarios. En ese sentido, los conflictos obreros y sociales construidos en Caras y Caretas están modelados de acuerdo a estos principios y las voces que componen su superficie, tanto redaccional como publicitaria, constituyen un discurso armónico afín a su línea política.

El tratamiento que Caras y Caretas manejó en torno a la Semana Trágica estuvo acorde con el carácter masivo, popular y enmarcado en lo que esta revista consideraba acorde a las capacidades y hábitos de lectura de su público lector. Por este motivo, la publicación concedió a la imagen un papel preponderante y esencial para relatar los hechos. En su edición del 18 de enero de 1919 el semanario hizo un especial que tituló como "La Semana Trágica", siendo la única publicación que definió los hechos con esa retórica hiperbolizada y sensacionalista, con cuyo nombre pasaron a la historia estos sucesos.

El título "La Semana Trágica" acuñado por la revista es una expresión que alude directamente a los sucesos de enero de 1919. El término referencia inmediatamente estos hechos después de 100 años de ocurridos. La frase está vinculada a una situación de habla específica y que remite a un contexto determinado.

"La Semana Trágica" es una frase que es capaz de mostrar la situación de enunciación de un hablante, cuya utilización dotó de sentido a la construcción periodística hecha por la revista. Se trata de un sintagma compuesto por tres morfemas, a saber: un 
artículo, un sustantivo y un adjetivo. Si desglosamos lingüísticamente la frase o el enunciado, en principio se encuentra el artículo "La", seguido por el núcleo de la frase, "Semana" y el adjetivo que cumple un rol modificador "Trágica". La deconstrucción de la frase permite observar que el sustantivo está acompañado de un adjetivo, que de acuerdo con Marafioti (1998), es un adjetivo afectivo o calificativo, porque involucra un sentimiento del enunciador. La publicación hizo una calificación sobre los hechos desde el punto de vista emocional, que tiene como intención influir en los lectores y modelar la recepción que desea de ese discurso periodístico. En ese sentido, la frase sintagmática "La Semana Trágica" condensa el mundo ideológico creado por la revista en el discurso enunciado ${ }^{3}$.

A través de las marcas discursivas explicadas, la revista instaló un juego de correspondencias para influir en el lector y convertir su posición editorial en una postura ideológica compartida con sus lectores. Esto también se corrobora con el discurso icónico y textual que prosigue al título en cuestión.

Durante esa semana, la prensa diaria informó sobre los sucesos violentos. Sin embargo, en Caras y Caretas se indica que "la crónica de los hechos nos la han referido los diarios, pero dada la situación anormal porque hemos pasado, ella ha sido muchas veces deficiente" (S/A, 1919: 48). Con esto, se justifica el apartado especial construido en torno a los sucesos, desde una perspectiva novedosa, en la que se privilegian los recursos tipográficos, lo cual se evidencia en el titular y en el manejo de las imágenes. Estos son recursos originales y únicos en la prensa del momento, distintos a la construcción netamente textual efectuada por los diarios más importantes del momento, como La Nación, La Prensa o La Época.

La revista difundió un apartado especial sobre la semana en cuya portada emplazó como título "Los abnegados de la semana". Los abnegados son un grupo de médicos, enfermeros y demás personal de la Asistencia Pública que prestaron sus servicios para atender a la población y a los heridos. Una fotografía a página completa muestra al equipo médico en cuestión, personal masculino en su totalidad. La gráfica tiene una leyenda o pie de fotografía en la que se destaca el altruismo y la dedicación de estos profesionales durante los días de las protestas violentas: "Parte del personal de médicos y practicantes de la Asistencia Pública, que durante varios días tuvieron que prestar servicios a la población, sin tener descanso y dando pruebas del más alto sentimiento altruista" (S/A, 1919: 35).

Luego de presentar a los miembros de la Asistencia Pública en la portada, la edición del 18 de enero de 1919 muestra de inmediato, en la página contigua, un gran titular que pone de manifiesto las marcas ideológicas del discurso construido sobre estos hechos. Con tipografía en caja alta y cuerpo superior se puede leer el título "La Semana

\footnotetext{
${ }^{3}$ Conviene indicar que hay un precedente previo a "la Semana trágica" en Cataluña. Algunos autores prefieren identificarla como la revolución de julio de 1909. Ver: Babiano, Pérez y Hurtado (2012).
} 
trágica". El interés de la publicación es capturar la atención del lector desde un título que adelanta, con contundencia, un hecho violento. Como se indicó previamente, se trata de un titular que busca una complicidad afectiva con el lector frente a los sucesos.

El discurso periodístico construido instaló la idea de que La Semana Trágica no fue un suceso aislado o individual que dejó unos muertos y heridos producto de una refriega en algunos lugares de la capital. Por el contrario, se trataba de una tragedia colectiva en la que podían derrumbarse los cimientos de la sociedad, el contrato social era el que estaba disolviéndose frente a una insurrección que amenazaba con extenderse y derribar a las clases dominantes, como las revoluciones comunistas y anarquistas que estallaban en Europa. De esta manera, justificó la restitución del orden vigente frente a la amenaza que supone la subversión frente al dominio establecido. Desde este propósito se entiende el despliegue gráfico e icónico efectuado al relato, cargado de contenido emocional.

Como es característico en Caras y Caretas, la imagen constituye el recurso gráfico esencial para emprender el relato y sobre todo destacar mediante fotografías que construyan fehacientemente el argumento que se quiere consolidar: las consecuencias negativas que la violencia callejera causó en la ciudadanía y en el espacio público. Es por ello que el titular "La Semana trágica" acompaña los encuadres fotográficos que muestran tranvías volcados, cadáveres y heridos, comercios e iglesias destruidas, un asilo de niñas huérfanas saqueado, entre otras escenas de lugares destruidos por las refriegas de esos días.

Las imágenes también proyectan la idea de una ciudadanía conmocionada y afectada por la paralización general, lo cual moviliza afectivamente al lector que vio su rutina o su vida cotidiana trastocada por la situación.

En una gráfica se puede ver cómo huelguistas le piden al chófer de un tranvía plegarse a la huelga. Otra fotografía de un grupo de personas junto a un vagón testimonia en su leyenda cómo los pasajeros estaban "tratando de convencer a los asaltantes para que los dejen continuar viaje en tranvía" (S/A, 1916: 44).

Se trata de poner de relieve a una sociedad afectada por estos hechos trágicos, sobre cuya responsabilidad se atribuye a los obreros anarquistas o anarcosindicalistas. Los subjetivemas "extremistas" y "maximalistas" son los más recurrentes en el discurso construido por Caras y Caretas, así como el resto de la prensa masiva más leída por el público del momento, como La Nación y La Prensa ${ }^{4}$. También se pueden leer expresiones como: "elementos sin patria", suerte de maleantes y "hombres ajenos a toda disciplina social".

\footnotetext{
4 Para la época, en Italia, los sectores más extremistas del socialismo eran denominados "maximalistas" y de allí la expresión que emplea la revista.
} 
La construcción periodística emprende un manejo gráfico que encuadra escenas de caos, desorden y drama colectivo. Se construye una posición ideológica contraria a los obreros insurrectos y en huelga. A continuación, las primeras líneas de la crónica periodística intitulada "La Semana Trágica" por la revista Caras y Caretas:

Buenos Aires ha presenciado varias huelgas, donde los obreros, en defensa de lo que creían su derecho, abandonaron el trabajo para lograr, por ese medio, resultado; a veces también, en la exaltación, se empleó la violencia, pero una huelga sangrienta, como la que hemos tenido que tolerar, eso nadie lo hubiera imaginado, ni puede atribuirse a trabajadores (S/A, 1919: 44).

El texto deja por sentado que no está en contra de las protestas reivindicativas de los trabajadores. Confirma lo que revelan los datos estadísticos de la época con respecto de las miles de huelgas ocurridas en esa época en el país, especialmente durante 1918 y 1919.

El discurso periodístico maneja recurrentes subjetivemas o valoraciones que dejan ver su posición ideológica, como "turbas", "revoltosos", "asaltantes", "atacantes", "pseudo huelguistas" "elementos subversivos" y en menor medida utiliza los apelativos "obreros", "huelguistas" o "maximalistas". Esto determina el eje fundamental del discurso difundido por el semanario. A continuación se evidencia la opinión de la publicación:

La causa de que se hayan producido demasías a las que no estábamos acostumbrados, y de que la violencia se haya llevado al extremo, ha sido porque a este movimiento se han mezclado, no ya obreros que pugnan por imponer un pliego de condiciones, o socialistas que desean hacer triunfar lo que creen su buena causa, sino ese elemento sin patria que aunque constituye por fortuna, minoría, quiso imponerse por la violencia; nos referimos a los maleantes, esos hombres ajenos a toda disciplina social, y extraños también a toda organización obrera (S/A, 1919: 44- 47).

Todo conflicto tiene unos actores involucrados, como se ha indicado. En el caso de la Semana Trágica, Caras y Caretas los identifica y ajusta dentro de su encuadre ideológico. De acuerdo con Borrat (1989), el conflicto social se origina en las relaciones de dominio de una sociedad, es decir, se trata de una situación conflictiva entre dirigentes y subordinados, con niveles de intensidad y violencia. En este caso, se trata de una huelga que tuvo como respuesta la represión armada por parte del Estado que tuvo como consecuencia más de cien muertos (Bilsky, 1984).

En cuanto a los actores involucrados, en primer orden se ubican los trabajadores huelguistas, quienes hacen exigencias reivindicativas y no tienen otro objetivo que lograr mejores condiciones laborales. Se agrupan en la FORA del IX Congreso. 
En segundo lugar, dentro del conflicto también operan aquellos que aprovechan el momento para iniciar una revolución. Estos eran en su mayoría trabajadores extranjeros, aunque también había nacionales, que militaban en el anarquismo y en el comunismo. Eran conocidos también como "anarcosindicalistas", identificados por el semanario como una amenaza para el orden social y un peligro para la nación. Contra estos últimos se enfila el discurso y todo el temario incorporado a propósito de estos sucesos.

La nacionalidad es un elemento retórico que está presente y que se utiliza como recurso para dirigir la crítica hacia el "elemento sin patria". Este sector se inclina por posiciones revolucionarias o "extremas" que auspiciaban una revuelta social para cambiar el orden imperante. De este modo, desde Caras y Caretas se construye un juicio moral para deslegitimar las acciones de esta especie de enemigo interno que amenaza la nación. Mediante el logos se establece el pathos, es decir, se vierte una retórica que promueve las emociones con el posible objetivo de persuadir para desencadenar una acción, o justificarla. En este caso el accionar se dirige hacia la aniquilación de este enemigo interno. Por esa razón expone:

Urge que los elementos sanos del país nos pongamos en guardia contra ciertos exaltados, que aprovechando de cualquier desavenencia entre patrones y obreros, ejercen presión para llevar las cosas a la violencia y cometer desmanes que repugnan a todo hombre honrado.

El derecho de petición es justo; pero el de imposición que los ácratas propalan, no puede aceptarse de ningún modo (S/A, 1919: 47).

Por esa razón, la incriminación directa se dirige hacia los trabajadores afines al anarcosindicalismo, tratados como suerte de enfermedad del cuerpo social, que debe ser extirpada. Se trata de la construcción de un discurso organicista o patológico de acuerdo con Rodrigo Alsina (1991).

Es pertinente mencionar que los trabajadores oriundos de países europeos como Italia, España, Francia, Alemania, entre otros, son los que trajeron a la Argentina las ideas socialistas, antiautoritarias, libertarias o ácratas. En ese sentido, se evidencia con esto que existe una continuidad histórica en las políticas asumidas por el Estado con respecto a los extranjeros que profesan ideologías subversivas, es decir, contrarias a los valores hegemónicos.

El tratamiento periodístico de Caras y Caretas en torno a la Semana Trágica demuestra la vigencia de una especie de estigma en contra del extranjero, aún en la etapa democrática. Valga indicar que la Ley de Residencia $N^{\circ} 4.144$ se mantuvo vigente en esta época. Dicha ley se aprobó en 1902 y solía conocerse como ley "antiargentina". Modolo (2009) refiere que fue un instrumento legal arbitrario, que tenía como fin controlar la protesta social y perseguir a los militantes anarquistas y socialistas, en su 
mayoría extranjeros oriundos de España e Italia. La ley facultaba al Poder Ejecutivo a expulsar extranjeros condenados o perseguidos por tribunales internacionales, así como ordenar la expulsión de extranjeros cuya conducta se consideraba comprometía la seguridad de la nación o perturbaba el orden público. También impedía la entrada de extranjeros al país por esos mismos motivos. Fue derogada el 1 de julio de 1958, durante el gobierno de Arturo Frondizi.

En el caso de las protestas de La Patagonia, cuya zona fue muy conflictiva durante el primer gobierno de Yrigoyen, la Ley de Residencia sirvió como instrumento disuasivo y de persecución contra quienes efectuaban manifestaciones de protesta pública. En el siguiente fragmento se evidencia de nuevo la oposición entre la nacionalidad y la extranjería. El segundo vendría a ser el otro ajeno a la nación, el bárbaro y el culpable de los males que atraviesa la sociedad:

De cuantos hechos se ha producido, no debemos inculpar a nadie; quizá es culpa de todos, pues con nuestra apatía, hemos tenido abiertas las puertas a todo elemento maleante del mundo entero, sin considerar que esa liberalidad de nuestras leyes no puede ser apreciada por gentes que desconocen todo sentimiento de patria, y que en la mayoría de los casos, si los estudiáramos de cerca, que ese elemento extraño que viene a nuestra tierra a provocar conflictos sangrientos, son gentes que en su mismo país son considerados indeseables y por lo tanto no tienen más recurso que la expatriación para escapar a la cárcel.

Nuestro gran Alberdi, dijo, en hora sagrada: "gobernar es poblar"; si, cierto; pero debemos saber con quién. No hemos estado formando nuestra nacionalidad durante años para verla destruida por hombres a quienes nada debemos, y que no son elementos útiles ni recomendables" (S/A, 1919: 61).

De acuerdo a este último comentario, los huelguistas, calificados per se como parias o apátridas, serían una suerte de malignidad del tejido social, producto de una hipotética nacionalidad malentendida, que habría que extirpar.

Esto indica una línea histórica de continuidad durante todo el siglo XX contra el extranjero como elemento extraño que hay que controlar por ser éstos quienes trajeron y multiplicaron las ideologías consideradas subversivas contra el orden y los valores tradicionales oligárquicos.

Este discurso patológico, basado en la discriminación o la xenofobia hacia el extranjero, elemento externo o "extraño", se elaboró contra quienes representaban una amenaza a los intereses de la sociedad y sobre todo a los intereses hegemónicos de las élites dominantes. Se inoculó así una especie de "pánico moral" (Kenneth, 2014), contra los que constituían una amenaza para los valores e intereses sociales. 
Siguiendo a Borrat (1989), toda publicación periódica es un actor político con intereses particulares y empresariales definidos a través de su línea editorial, al servicio de sus objetivos: lucrar e influir. En ese sentido, el tratamiento de la revista hacia la Semana Trágica se circunscribe en el marco de un conflicto de poder en el que, como medio masivo, es actor participante y además afectado en cuanto al esfuerzo y los riesgos que representaban la difusión de las gráficas y de todo el material difundido. A continuación se aprecia esto en el siguiente fragmento:

Por dolorosa experiencia sabemos que los huelguistas revolucionarios son enemigos de la fotografía, pero la profesión tiene exigencias y como nosotros no podemos hacer periodismo por versiones, tuvimos que ser heroicos por fuerza $y$ atrevernos a todo para presentar una serie de fotografías interesantes, que esperamos que nuestros lectores apreciarán, pues representa un esfuerzo grande, dado el estado de anormalidad para conseguirse medios de locomoción, y de hallar fotógrafos dispuestos a mezclarse con su máquina en lugares donde la vida estaba expuesta a cada momento (S/A, 1919: 48).

De acuerdo a la crónica de la publicación, no sólo los fotógrafos se vieron afectados para cubrir la situación, sino también los reporteros, quienes tuvieron problemas para recabar información.

El tratamiento dado por la revista a la Semana Trágica deja por sentado que los obreros huelguistas son los violentos y fueron los responsables de las refriegas, los muertos y el caos general. Es pertinente retrotraer la versión que ofrece en relación a los hechos ocurridos en el cementerio de La Chacarita el día 9 de enero, fecha en que se generaron los disturbios y se proclamó la huelga general: “Allí, algunos exaltados por los hechos presenciados, y por los discursos de los anarquistas que los incitaron a la violencia, se lanzaron a cometer desmanes, los que al ser repelidos por la fuerza pública, ocasionaron gran número de víctimas" (S/A, 1919: 51). Unas líneas más adelante indica que "Por fortuna, el movimiento no estaba organizado, y fue [sic] posible atajar el mal, por medio de las tropas" (S/A, 1919: 51). Con esto, la publicación manifiesta su inclinación favorable hacia la represión por parte de la policía y el Ejército.

Este manejo retórico de la revista coincide con lo que Rodrigo Alsina (1991) ha denominado discurso patológico, que justifica la violencia porque provendría de individuos con personalidades patológicas. Se toma la violencia como una perturbación mental de unos individuos desadaptados y no una consecuencia política de la desigualdad económica y social.

Las fotografías también constituyen un factor que indica la postura proclive a la represión por parte del Ejército. Son diversas las imágenes que proyectan a los miembros de la policía y las tropas del Ejército, entre ellos los Granaderos a Caballo, la 
Infantería, Artillería y conscriptos que participaron ese día para repeler las manifestaciones. Los muertos de esa fecha evidencian la dura respuesta de parte del Estado en estos hechos.

Como ya se indicó previamente, el manejo retórico de la revista tendió a ser recurrente en el efecto de proyectar a quienes se mantuvieron apegados al orden y al trabajo, sin adherirse a la subversión o la huelga general. Se trata de utilizar sujetos ejemplarizantes y aleccionadores mediante los cuales se sanciona moralmente a un colectivo insurrecto, desordenado e incivilizado. Desde otra perspectiva, la intervención de estos héroes anónimos posibilitó la atención a las víctimas y contribuyó a aliviar el clima de desasosiego general.

No solo los médicos y practicantes de medicina reciben el reconocimiento por su fidelidad al orden, sino también a las telefonistas, los periodistas, los miembros del Ejército, de la Armada, los conscriptos, la policía y un sector "patriótico" que empezó a posicionarse en la esfera pública, La Liga Patriótica Argentina. A todos estos la publicación los incorpora como protagonistas y héroes de la jornada, tanto en su edición del 18 de enero como en el número de la semana siguiente, con fecha 25 de enero de 1919. El texto dedicado a las telefonistas reúne los argumentos retóricos para la corrección social:

Durante los días de huelga en que se paralizó todo, las telefonistas han dado una nota grata, no abandonando el servicio y, atendiendo al público de una manera tan excelente, que sería cosa de recomendarles el sistema durante todo el año; pero en fin, debemos absolverlas de todos sus pecadillos en gracias a que ellas han contribuido con su trabajo a tranquilizar muchos hogares; y nosotros, los periodistas, sabemos mejor que nadie lo que vale un buen servicio telefónico (S/A, 1919: 44).

Este apartado dedicado a las telefonistas con el título "Las simpáticas y activas telefonistas" en la edición del 25 de enero, que está acompañado de fotografías de estas mujeres en sus puestos de trabajo, tiene un sentido de corrección social y un llamado a la edificación ciudadana a través del trabajo. Se trata en este caso de un recurso retórico que incorpora a los buenos, a los ciudadanos ejemplares, mientras excluye a los "malos", a los contrarios o a los enemigos internos que amenazaron el sistema. De esa forma, construye un discurso crítico hacia la sociedad para coadyuvar a la creación de una ciudadanía que tome conciencia de sus supuestos errores.

El encauzamiento social se orientaba hacia establecer modelos y crear nuevos sentidos, en los cuales la sociedad debía reconocerse y reconfigurarse. De esta manera, la revista, como actor político, contribuyó simbólicamente a configurar mecanismos de docilidad-utilidad para propiciar la disciplina que debían tener los nuevos ciudadanos. Para ello, había que construir el discurso normalizador que 
establecía quiénes eran los ciudadanos ejemplares, cuyos comportamientos debían emularse y quiénes eran los enemigos o los ajenos al cuerpo social, que debían en consecuencia expulsarse para edificar la nación.

Con este discurso también se legitima la actuación de las fuerzas represivas, la policía y el Ejército junto a los grupos parapoliciales nucleados en la Liga Patriótica. Conviene mencionar que tanto en la edición del 18 de enero como en la de la semana siguiente, el 25 de enero, se publicaron imágenes de la "manifestación patriótica", se trataba en realidad de una marcha organizada por la Liga.

La Liga Patriótica Argentina tuvo una proyección significativa en Caras y Caretas, especialmente en la reseña de conflictos obreros posteriores, como ocurrió en 1922 con las huelgas de los peones de las estancias ovejeras en la provincia de Santa Cruz, quienes luchaban por mejores salarios y condiciones laborales dignas. El reclamo culminó en la masacre de 1.500 peones, de acuerdo con Bayer (2013).

En esa oportunidad, desde la revista se legitimaron nuevamente las prácticas represivas del Ejército contra los trabajadores, a quienes se les calificó de "bandoleros". En la represión participó activamente la Liga Patriótica, lo cual fue reseñado por Caras y Caretas, en la página 58 de la edición del 11 de febrero de 1922, bajo el titulo "La acción de la Liga Patriótica en los territorios del sud". En esta información, el semanario difundió tres fotografías de Manuel Carlés, líder de la Liga, quien fue a la región posterior a la masacre y ofreció un discurso público en Río Gallegos, capital de la provincia de Santa Cruz, "con motivo de los sucesos sangrientos acaecidos en el sud y que son de conocimiento público" (S/A, 1922: 58).

La Liga Patriótica nucleaba a un sector patronal, elitista y profundamente conservador, con rasgos fascistas, como lo subrayó Halperín (1999). Este sector creó un grupo armado parapolicial en reacción a la política laboral del gobierno de Hipólito Yrigoyen favorable a los sindicatos, especialmente durante las huelgas marítimas y ferroviarias.

La Liga Patriótica surgió como una respuesta de la élite económica frente al temor de que el gobierno radical no fuese suficientemente drástico en reprimir las huelgas. Godio (1972) indica que bajo lemas como "defensores del orden", "defensa de la nacionalidad" o defensa de lo que denominaban la "argentinidad", se organizaron grupos terroristas para reprimir severamente las huelgas. La organización hacía colectas para pagar a soldados, policías y marineros a cambio de que éstos reprimiesen a los trabajadores.

Este discurso legitimó la represión sobre la base de realidades dicotómicas de "malos" y "buenos" y bajo principios de superioridad e inferioridad. A través de estos postulados ideológicos se posibilitó la proscripción del ala anarquista y comunista de los obreros en huelga. 
Al mismo tiempo, existió la intencionalidad política de Caras y Caretas por mostrar un frente unitario en favor del orden establecido, en el que se agrupaban los miembros de la élite dominante, las fuerzas de seguridad y por ende el gobierno, en contra de los supuestos factores externos que amenazaban la nacionalidad.

La nación estaba en riesgo y debía sobreponerse frente al ataque y las amenazas de quienes pretendían hacerla sucumbir. Esta premisa fue parte de la ideología que manejó el discurso del semanario a propósito de los hechos de la Semana Trágica. En la edición N 1.060 del 25 de enero de 1919, se puede ver una mujer alta, vestida con los colores albicelestes de la bandera Argentina y con el gorro rojo, símbolo de libertad. La esbelta mujer dirige los caballos que tiran los instrumentos de arado del suelo, los cuales son manejados por un campesino o jornalero. Esta ilustración tiene debajo un texto, intitulado "En las horas amargas". El fragmento expresa:

"Sigue, hijo mío, a mi lado y acompáñame constante con tu labor y tu esfuerzo; cumple tu noble misión y orgulloso de tu nombre, sin vacilar un instante, trabaja en la obra fecunda de la civilización" (S/A, 1919: 1).

La mujer es la república Argentina, que encauza a sus súbditos ciudadanos para que retomen la sindéresis, se ajusten al orden mediante el trabajo. El arado tirado por caballos es el símbolo del trabajo y del esfuerzo que debe retomarse. Se evoca la tierra fértil, la labranza, la agricultura. Se entiende con esto que el progreso y la civilización se alcanza sólo a través del campo, que ha sido el pilar del modelo económico primario de agroexportación sostenido por la élite dominante.

Se trata de un discurso asimilacionista (Torodov, 2003) que intentó encauzar, convertir o hacer entrar en razón a quienes estaban desviados o fuera de la norma. Hay una posición axiológica o binaria entre "buenos" y "malos", o un "nosotros" y un "ellos", es decir, se establecieron realidades dicotómicas o pares antagónicos.

Caras y Caretas busca la complicidad con el lector en la lucha por civilizar y entronizar en el colectivo el orden social. Busca entronizar la necesidad de la domesticación, la civilización y normalización social para superar el escenario de "barbarie" impuesta por unos extraños a la nación, por los extranjeros que quieren subyugarla. De allí que en la imagen sea la Argentina, es decir, la nación o la nacionalidad, la que se erige y reafirma en libertad contra los supuestos invasores. 


\section{Las posturas de los principales periódicos}

Resulta obvio indicar que un hecho violento de tanta trascendencia como lo fue la Semana Trágica argentina tuvo un tratamiento periodístico significativo en los principales diarios del país. Lo que merece precisar es que los medios de prensa de mayor circulación del momento manejaron una postura ideológica similar a la de Caras y Caretas. Para este análisis se toman en consideración los tres periódicos de mayor circulación y gravitación política durante esos años, La Nación, La Prensa y La Época. Estos diarios tuvieron en común el hecho de hacer un llamado desde el primer momento de los sucesos al orden y la civilidad de los ciudadanos para restituir la normalidad.

El diario La Nación en los primeros días los tituló como "La agitación obrera" o "El paro general", pero el 13 de enero se puede leer la información concerniente a los hechos bajo el título "La agitación ácrata en la capital". Los calificativos como ácrata, extremistas, maximalistas, subversivos o "rusos" eran algunos términos empleados por el diario para referirse a los huelguistas.

En los subtítulos del día 13 de enero La Nación destaca en sus subtítulos frases como: "Descubrimiento de un plan maximalista"; "La policía detiene a los cabecillas"; "Comienza a restablecerse el tráfico de tranvías"; "La agitación en el interior". En las líneas de esta información, subrayó la actuación del Ejército frente a los sucesos. A continuación se ofrece un fragmento de esto:

Tenemos un placer de hacer constar que la enorme mayoría de la ciudad no sufrió durante el día de ayer violencias, tiroteos, ni acto alguno que implicara anormalidad. Es, pues, necesario que los ciudadanos reabran sus negocios, tiendas y escritorios, o, de lo contrario, habrá que creer que esas personas son los mayores auxiliares de las huelgas. (...) el público está necesitando vida normal; la vigilancia es abundante; el general Dellepiane es una garantía; la adhesión de los mejores y más sinceros al principio del orden es sólidamente efectiva (S/A, 1919: 5).

El periódico convocó así a volver al cauce de la normalidad y subrayó la necesidad de que la población se someta a las reglas del sistema y desapruebe en todo momento la acción de los huelguistas. Sobre estos últimos, La Nación llamó al apoyo decidido a la nación al señalar que los hechos de la Semana trágica forman parte de "un plan subversivo ácrata", con eventuales conexiones internacionales. Esto se evidencia en la siguiente nota:

A propósito del plan subversivo tramado por los elementos ácratas de esta capital en combinación con los de Montevideo, nuestro corresponsal en la vecina 
orilla nos telegrafía las siguientes informaciones, completando las amplias que nos transmitiera el día anterior (...) Ninguna novedad se ha producido en las últimas 24 horas con respecto al levantamiento similar al de ésa, que también se proponían llevar a la práctica aquí los agitadores rusos maximalistas y otros elementos ácratas (S/A, 1919: 5).

Este discurso es similar al manejado por diarios como La Época, el periódico oficial del partido radical argentino. Bilsky hace referencia al discurso de este diario:

Se trata de una tentativa absurda, provocada y dirigida por elementos anarquistas, sin disciplina social, extranjeros a las verdaderas organizaciones de los trabajadores". Subraya el hecho de que se trata de una "minoría subversiva" contra la cual "basta oponer la gente del orden (Bilsky, 1984: 119)"

La posición de estos medios tiene similitudes con los de la revista Caras y Caretas en el sentido de descalificar a los obreros huelguistas y pedir a la ciudadanía y a las fuerzas represivas del Estado a restablecer al orden. Justificaban estos diarios la represión y el asesinato como forma de normalizar la sociedad. A esto se agrega que el blanco de la represión por estos días, como lo indicó Bilsky (1984) fueron los judíos, a quienes se les perseguía en sus barrios e instituciones bajo el apelativo de "rusos".

La Semana trágica desencadenó un antisemitismo que impregnó los diarios y las publicaciones con mayor circulación en ese momento. La Nación emplazó el 14 de enero una información que daba cuenta de la detención de los supuestos dirigentes anarcosindicalistas, bajo el título "El Plan subversivo- Detención de los cabecillas en esta capital”. Esta nota expresaba lo siguiente:

Por toda la ciudad circuló ayer la noticia de que la autoridad policial había allanado una casa, sorprendiendo dentro de ella en grave deliberación, a los 40 miembros dirigentes del "primer soviet de la república federal de los soviets argentinos". Agregábase que entre los presos figuraba el presunto presidente o dictador de la república del referido soviet y su futuro jefe de policía (S/A, 1919: $6)$.

Esta información, que se acompaña de dos fotografías del rostro de los detenidos, Pedro Wald y Juan Selestud, a quienes se señalaba como enemigos o suerte de parias que atentan contra la república. Este tratamiento evidencia la idea que se propagó por aquellos días acerca de que los sucesos de la Semana Trágica formaban parte de una conspiración subversiva internacional con militantes o "soviets" rusos incluidos para encabezar una rebelión obrera.

Con respecto al diario La Prensa, el tratamiento es similar al observado en los diarios mencionados. Como lo indica Godio (1972), este diario se manifestó abiertamente a

\footnotetext{
${ }^{5}$ Las comillas de la cita corresponden al autor.
} 
favor de la violencia estatal. El siguiente editorial publicado el 12 de enero demuestra su posición favorable a la represión:

Habíamos alentado la esperanza de que el día de ayer sería el último en la serie de acontecimientos anormales y terribles que hemos vivido. Los nuevos sucesos violentos burlaron aquellas esperanzas y aun cuando el sentimiento general estimula al gobierno para que adopte las medidas más enérgicas y prudentes, todavía no podemos asegurar hasta cuándo durará este inconcebible estado que degrada los anhelos del enorme vecindario de esta Capital y pone en peligro la vida de millares de honestos y leales servidores del orden público (Godio, 1972: 177).

Este fragmento muestra que el diario La Prensa también justificó la represión e incluso de una manera más abierta y directa. Sin embargo, Godio (1972) advierte que la diferencia con este diario es que propuso una legislación obrera actualizada, que estableciese la conciliación obligatoria de los sindicatos ante conflictos, una postura mucho más de avanzada que las posiciones conservadoras de La Nación y de la que se observó en la revista Caras y Caretas. Esta propuesta la hizo en un editorial del día 11 de enero:

Ante la omisión de una legislación que obligue a recurrir a temperamentos de conciliación y arbitraje, ha debido, de acuerdo a la misión que por Carta Orgánica compete al Departamento Nacional del Trabajo, ofrecerse la mediación amistosa de esta institución hubiera bastado para evitar complicaciones en el conflicto originado" (Godio, 1972: 176).

Respecto de esto, Tarcus (2017) refiere que Argentina vivió por esta época un "trienio rojo", por lo que acontecimientos como el de la Semana Trágica o las huelgas de la Patagonia no pueden comprenderse por fuera de este contexto nacional y global de radicalización política e ímpetu revolucionario ${ }^{6}$. Como se señaló previamente, el imaginario soviético había penetrado fuertemente el movimiento obrero argentino, cuyos principales partidarios se agruparon en la FORA del V Congreso. En ese sentido, la Semana Trágica significó la coincidencia de la élite conservadora y del gobierno radical, respecto de la necesidad de aislar a este sector extremista de la sociedad. De allí se entiende el tratamiento periodístico de los diarios más influentes de la época y de revistas como Caras y Caretas.

\footnotetext{
${ }^{6}$ En 1920 y 1921, la Patagonia argentina se convirtió en una región muy conflictiva debido a las diversas huelgas de los peones de estancias ovejeras para exigir reivindicaciones salariales y adecuadas condiciones de trabajo e higiene. Frente a estas huelgas el Estado reaccionó de manera violenta, con el apoyo de la Liga Patriótica Argentina. Junto con la Semana Trágica, los hechos de la Patagonia son los más violentos y sangrientos de esta época.
} 


\section{Referencias bibliográficas}

ALTABELLA, J. (1953): Teoría e historia del periodismo gráfico, Madrid, Gráficas Aragón.

BABIANO, J., Pérez, J. y Hurtado, J. (2013): "La huelga general en el siglo XX español: retórica, mito e instrumento" en Estudios, $\mathrm{N}^{\circ}$ 66. Madrid: Fundación $1^{\circ}$ de Mayo. Disponible en: http://revistas.ucm.es/index.php/HICS/article/view/43971/41578 [Consulta: 01-06-2018].

BAJTIN, M. (1995): La cultura popular en la Edad Media y en el Renacimiento. El contexto de François Rabelais, Madrid, Alianza Editorial.

BILSKY, E. J. (1984): La semana trágica, Buenos Aires, Centro Editor de América Latina.

BOURDIEU, P. (2012): La distinción. Criterio y bases sociales del gusto, Barcelona, Taurus.

BORRAT, H. (1989): El periódico, actor político, Barcelona, Editorial Gustavo Gili S.A.

BAYER, O. (2013): La Patagonia rebelde, Buenos Aires, Editorial Planeta.

CABALLERO WANGÜERMERT, F. y Román Porter, M. (2013): "El humor gráfico en la prensa gallega y portuguesa (1870-2000). Semejanzas y diferencias" en Historia y Comunicación Social, N²18, octubre 2013.

CHARTIER, R. (1992): El mundo como representación, Barcelona, Legasa.

DÍAZ, C. L. (2007): Combatiendo la ignorancia aprendida: la prédica jauretcheana en la revista Qué: 1955-1958, La Plata, UNLP.

DÍAZ JUAREZ, M.V. (2018): Narrar la historia. La internacionalización de las ideas en las portadas de Punch-Puk- Caras y Caretas. Tesis doctoral. Universidad Complutense de Madrid. Disponible en internet (28-05-2018) http://eprints.ucm.es/46421/1/T39582.pdf

DI MARE, M. F. (2010): "Cultura y sensibilidad en la revista venezolana El Cojo llustrado" en Ensayo y Error N 39, pp. 129-145.

DEVOTO, F. (2002): Nacionalismo, fascismo y tradicionalismo en la Argentina moderna. Una historia, Buenos Aires, Siglo Veintiuno Editores.

- (2002): Historia de la inmigración en la Argentina, Buenos Aires, Sudamericana.

DUCROT, O. (2001): El decir y lo dicho, Buenos Aires, Edicial.

FALCÓN, R. y Monserrat, A. (2000): “Estado, empresas, trabajadores y sindicatos” en Falcón, R. (comp.): Nueva Historia Argentina. Democracia, conflicto social y 
renovación de ideas (1916-1930), Buenos Aires, Editorial Sudamericana, pp. 151193.

GERCHUNOFF, P. (2016): El eslabón perdido. La economía política de los gobiernos radicales (1916-1930), Buenos Aires, Edhasa.

GODIO, Julio (1985): La semana trágica de enero de 1919, Buenos Aires, Hyspamerica.

GUTIÉRREZ, L. y Romero, L. A. (2007): Sectores populares, cultura y política. Buenos Aires en la entreguerra, Buenos Aires, Siglo XXI Editores.

HALPERÍN DONGUI, T. (1999): Vida y muerte de la República verdadera, Buenos Aires, Ariel.

HOROWITZ, Joel (2015): El radicalismo y el movimiento popular (1916-1930), Buenos Aires, Edhasa.

KENNETH, T. (2014): Pánicos morales, Bernal, Universidad Nacional de Quilmes.

MARAFIOTI, R. (1998): Recorridos semiológicos. Signos, enunciación y argumentación, Buenos Aires, Eudeba.

MODOLO, V. (2009): "La política de expulsión de extranjeros en Argentina. Continuidad o quiebre en la actual Ley de Migraciones", en Actas X Jornadas Argentinas de Estudios de Población, Asociación de Estudios de Población de la Argentina, Catamarca, 2009.

MCGEE DEUTSCH, S. (2003): Contrarrevolución en la Argentina, 1900-1932. La Liga Patriótica Argentina, Buenos Aires, Universidad Nacional de Quilmes.

PITTALUGA, R. (2015): Soviets en Buenos Aires. La izquierda de la Argentina ante la revolución en Rusia, Buenos Aires, Prometeo Libros.

ROCK, D. (2010): El radicalismo argentino. 1890-1930, Buenos Aires, Amorrortu editores.

RODRIGO AISINA, M. (1991): Los medios de comunicación ante el terrorismo, Barcelona, Icaria Editorial.

ROMANO, E. (2004): Revolución en la lectura. El discurso periodístico-literario de las primeras revistas ilustradas rioplatenses, Buenos Aires, El Calafate Editores.

ROGERS, G. (2008): Caras y Caretas: cultura, política y espectáculo en los inicios del siglo XX argentino, La Plata, Universidad Nacional de La Plata.

SAÍTTA, S. (2013): Regueros de tinta. El diario Crítica en la década de 1920, Buenos Aires, Siglo Veintiuno Editores. 
SEGADO BOJ, F. (2007): "El espíritu del 12 de febrero y el fantasma de la crisis económica de 1974: un análisis a través del humor gráfico" en Historia y Comunicación Social, $\mathrm{N}^{\circ}$ 12. Disponible en internet (30-05-2018) http://revistas.ucm.es/index.php/HICS/article/view/HICS0707110189A/19081

TARCUS, H. (2017): “La recepción argentina de la Revolución Rusa. 1917-1930", Conferencia presentada en el evento La revolución de octubre de 1917 en Rusia y su papel en la historia mundial, Novosibirsk.

THOMPSON, E. P. (1989): La formación de la clase obrera en Inglaterra, Barcelona, Crítica.

TZVETAN, T. (2003): La conquista de América. El problema del otro, México, Siglo Veintiuno.

ZAIDA, M. y Suriano, J. (2014): La sociedad del trabajo. Las instituciones laborales en la Argentina (1900-1955), Buenos Aires, Edhasa.

\section{Fuentes hemerográficas}

La Nación (1919, 11 de enero). “Agitación obrera- El paro general”, Nº 19.962

La Nación. (1919, 13 de enero). “La agitación ácrata en la capital”, № 16.964.

La Nación (1919, 14 de enero) "El Plan subversivo- Detención de los cabecillas en esta capital”, № 16.965 .

Caras y Caretas (1917, 13 de octubre), N 993.

Caras y Caretas (1919, 18 de enero). "Los abnegados de la semana”, № 1059.

Caras y Caretas (1919, 25 de enero). "Las simpáticas y activas telefonistas", № 1060.

Caras y Caretas (1922, 22 de enero). "Los bandoleros en el territorio Santa Cruz", N 1216. 